\title{
ANALISIS KESALAHAN PENULISAN HURUF KAPITAL PADA KARANGAN NARASI MENGGUNAKAN PEDOMAN UMUM EJAAN BAHASA INDONESIA (PUEBI)
}

\author{
Rohma Uswatun Khasanah ${ }^{1}$, Cicih Wiarsih ${ }^{2}$, Asih Ernawati ${ }^{3}$ \\ 1,2,3 PGSD, Universitas Muhammadiyah Purwokerto \\ 1' rahma.us.us@gmail.com, ${ }^{2}$ cicihwiarsih.umpwt@gmail.com, \\ asihernawati@gmail.com
}

Received: April 25, 2021 Revised: April 29, 2021 Accepted: May, 2021

\begin{abstract}
ABSTRAK
Penelitian analisis kesalahan penulisan huruf kapital pada karangan narasi menggunakan Pedoman Umum Ejaan Bahasa Indonesia (PUEBI) dilakukan karena masih sering dilakukan oleh peserta didik, yang mengalami kesulitan dalam hal penulisan huruf kapital yang benar sesuai dengan aturan Pedoman Umum Ejaan Bahasa Indonesia (PUEBI). Penelitian ini bertujuan untuk mengetahui kesalahan penggunaan ejaan huruf kapital yang dilakukan peserta didik dalam menulis karangan narasi. Jenis penelitian ini yaitu penelitian kualitatif, dengan partisipan guru kelas V B, peserta didik kelas V B, dan kepala sekolah. Data pada penelitian ini berupa dokumen tulisan peserta didik yang berbentuk karangan narasi dan hasil wawancara dengan bantuan aplikasi google form. Analisis data pada penelitian ini menggunakan model Miles and Huberman. Hasil penelitian menunjukkan bahwa total kesalahan yang dilakukan oleh peserta didik yaitu sejumlah 380 kesalahan yang terdiri dari penggunaan huruf kapital pada awal kalimat dan tengah kalimat, nama geografi, dan nama bulan. Upaya yang dilakukan guru dalam mengatasi kesulitan tersebut yaitu dengan cara mencari referensi tambahan dan menambah buku-buku pegangan guru.
\end{abstract}

Kata Kunci: penulisan huruf kapital, menulis karangan narasi, PUEBI

\section{PENDAHULUAN}

Bahasa Indonesia merupakan bahasa resmi yang digunakan oleh negara Indonesia. Bahasa Indonesia memiliki fungsi salah satunya sebagai alat komunikasi antar berbagai daerah. Hal itu tercantum dalam Undang-Undang No 24 Tahun 2009 tentang bendera, bahasa, lambang negara, serta lagu kebangsaan pada pasal 25 Ayat 2 yang berbunyi:

Bahasa Indonesia sebagaimana dimaksud pada ayat (1) berfungsi sebagai jati diri bangsa, kebanggaan nasional, sarana pemersatu berbagai suku bangsa, serta sarana komunikasi antar daerah dan antar budaya daerah. 
Bahasa Indonesia berdasarkan Undang-Undang di atas merupakan bahasa resmi yang digunakan sebagai sarana alat komunikasi antar berbagai daerah tentunya dalam berkomunikasi sesuai dengan kaidah penggunaan bahasa Indonesia yang baik dan benar. Bahasa Indonesia itu sendiri memiliki empat aspek keterampilan yaitu menyimak, berbicara, membaca, dan menulis, keempat aspek dalam berbahasa tersebut dilaksanakan secara terpadu. Berdasarkan keempat aspek tersebut diharapkan setiap pengguna bahasa Indonesia memiliki kemampuan yang baik dalam berkomunikasi baik secara lisan maupun tulisan. Keberhasilan pendidikan ditentukan salah satunya dengan penguasaan bahasa. Bahasa merupakan alat komunikasi yang digunakan oleh manusia untuk berinteraksi satu sama lain, melalui bahasa seseorang dapat memperoleh informasi. Keterampilan berbahasa (Tarigan, 2015: 1) dalam kurikulum di sekolah mencakup empat keterampilan, yaitu keterampilan menyimak atau mendengarkan, keterampilan berbicara, keterampilan membaca, dan keterampilan menulis. Dari empat keterampilan di atas yang disampaikan oleh Tarigan salah satunya yang dianggap sulit adalah menulis. Peserta didik mengalami kesulitan dalam hal menulis sehingga peserta didik banyak mengalami kesalahan dalam hal penulisan kalimat.

Menulis merupakan kegiatan mengungkapkan ide atau gagasan yang ada dalam pikiran dalam bentuk tulisan, menulis menurut Nurudin (2007: 4) merupakan segenap rangkaian kegiatan seseorang dalam rangka mengungkapkan gagasan dan menyampaikannya melalui bahasa tulis kepada orang lain agar mudah dipahami. Menulis menurut pendapat Tarigan (2013: 22) ialah menurunkan atau melukiskan lambang-lambang grafik yang menggambarkan suatu bahasa yang dipahami oleh seseorang, sehingga orang lain dapat membaca lambang- lambang grafik tersebut kalau mereka memahami bahasa dan gambaran grafik itu. Berdasarkan pendapat di atas dapat disimpulkan bahwa menulis dapat dikatakan sebagai suatu keterampilan yang sulit untuk dipahami peserta didik apabila dibandingkan dengan jenis-jenis keterampilan yang lainnya, karena melalui menulis kita tidak hanya menuangkan pikiran yang ada melainkan mengembangkan kalimat yang ada sehingga menjadi kalimat yang terstruktur sesuai dengan kaidah Pedoman Umum Ejaan Bahasa Indonesia (PUEBI).

Keterampilan menulis tidak dapat dimiliki secara otomatis melainkan melalui suatu proses dengan cara berlatih menulis dengan teratur. Menulis dalam prosesnya membutuhkan waktu lama untuk dapat menyusun beberapa kalimat menjadi sebuah

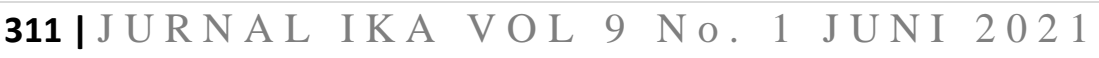


paragraf. Menulis penting untuk dipelajari bagi peserta didik karena melalui menulis maka peserta didik akan berusaha untuk mengasah kreativitas daya pikirnya, sehingga akan tercipta tulisan yang menarik dan tentu saja sesuai dengan Pedoman Umum Ejaan Bahasa Indonesia (PUEBI).

Penelitian yang telah dilakukan oleh Mansur, Q. Djariyo \& Mudzanatun pada tahun 2018, dengan judul "Kemampuan Siswa Sekolah Dasar Dalam Penggunaan Huruf Kapital Pada Teks Di Kebumen”. Hasil penelitian tersebut menunjukkan bahwa banyak terjadi kesalahan peserta didik dalam penggunaan huruf kapital pada penulisan laporan pengamatan. Kesalahan tersebut antara lain penggunaan huruf kapital pada awal kalimat, penggunaan huruf kapital ketika menuliskan nama geografi, nama hari, dan nama bulan. Kesalahan yang terjadi pada hasil laporan pengamatan peserta didik kelas V SD N 2 Wonoharjo yaitu disebabkan kurang pahamnya peserta didik terhadap aturan penggunaan Bahasa Indonesia yang baik dan benar. Hasil dari penelitian tersebut dapat diambil kesimpulan bahwa masih banyak peserta didik yang mengalami kesalahan dalam penggunaan huruf kapital, hal ini disebabkan karena kurang pahamnya peserta didik terkait dengan penggunaan pedoman yang sesuai dalam penulisan. Pemahaman peserta didik dalam hal pedoman penulisan merupakan sesuatu hal mendasar yang harus diketahui peserta didik.

Hasil wawancara dengan guru kelas V B SD Negeri 1 Sokaraja Kulon, ditemukan permasalahan bahwa masih terdapat banyak peserta didik apabila diminta untuk membuat kalimat masih belum efektif dan cenderung belum sesuai dengan kaidah Pedoman Umum Ejaan Bahasa Indonesia. Peserta didik banyak mengalami kendala dalam menulis kalimat meliputi penggunaan huruf kapital, serta penggunaan kalimat yang tidak efektif. Pada hal ini penggunaan kalimat yang tidak efektif yaitu peserta didik masih melakukan pengulangan pada kalimat sebelumnya yang sebenarnya dapat disampaikan secara efektif serta penggunaan subjek predikat objek yang masih terdapat kekeliruan. Berdasarkan permasalahan tersebut, guru sudah melakukan beberapa upaya untuk membantu peserta didik dalam menulis kalimat yang benar, akan tetapi masih saja terdapat peserta didik yang mengalami kesulitan. Salah satu upaya guru dalam mengatasi hal tersebut yaitu dengan cara mengoreksi secara langsung hasil pekerjaan peserta didik kemudian guru memberitahu kesalahan dalam penulisan kalimat dan penulisan huruf kapital yang disusun oleh peserta didik. 
Berdasarkan permasalahan yang ditemukan, peneliti tertarik untuk melakukan penelitian dengan judul “Analisis Kesalahan Penulisan Huruf Kapital Pada Karangan Narasi Menggunakan Pedoman Umum Ejaan Bahasa Indonesia (PUEBI). Kesulitan peserta didik dalam hal menulis kalimat dan penulisan huruf kapital yang baik perlu dilakukan adanya analisis karena apabila tidak dilakukan analisis maka guru tidak akan mengetahui kesulitan yang dihadapi oleh peserta didik dalam penulisan huruf kapital pada karangan narasi. Diperlukan adanya peran guru dalam hal mengatasi kesulitan peserta didik tersebut, sehingga apabila guru sudah mengetahui hal yang menjadi penghambat peserta didik dalam mengembangkan kemampuan menulis karangan serta penulisan huruf kapital maka guru secara perlahan dapat mengatasi permasalahan tersebut apabila terjadi dikemudian hari, dengan dilakukannya analisis maka akan mengatasi kebiasaan peserta didik melakukan kesalahan dalam penulisan huruf kapital sehingga tidak akan terjadi unsur kebiasaan dalam melakukan kesalahan penulisan huruf kapital pada peserta didik.

\section{METODE}

Penelitian ini menggunakan jenis pendekatan penelitian kualitatif. Penelitian ini termasuk kedalam penelitian kualitatif dengan metode deskriptif. Penelitian kualitatif bersifat deskriptif menurut Asrori dan Ali (2014 : 123) yaitu mendeskripsikan makna data atau fenomena yang dapat ditangkap oleh pelaku riset, dengan menunjukkan buktibuktinya. Pemaknaan terhadap fenomena itu bergantung pada kemampuan dan ketajaman pelaku riset dalam menganalisisnya. Penelitian ini dilaksanakan pada tanggal 25 Juli 2020 pada tahun ajaran 2020/2021. Adapun tempat penelitian ini dilaksanakan di SD Negeri 1 Sokaraja Kulon, Kecamatan Sokaraja, Kabupaten Banyumas. Partisipan dalam penelitian ini terdiri dari Kepala sekolah, guru kelas V B, dan peserta didik. Teknik pengumpulan data dalam penelitian ini yaitu dengan melakukan wawancara berbantu aplikasi google form, dan dokumen tulisan peserta didik.

Peran penelitian merupakan rangkaian dari metodologi penelitian kualitatif. Peran peneliti menurut Creswell (2019: 277) menjelaskan bahwa peran peneliti dianggap sebagai instrument primer dalam pengumpulan data kualitatif maka di bagian awal penelitian diperlukan adanya identifikasi terhadap nilai, asumsi, dan bias personal (peneliti). Teknik analisis data yang digunakan menggunakan tahapan pelaksanaan analisis menurut Miles and Huberman (Asrori dan Ali, 2014: 130) sebagai berikut: (a) 
Reduksi data, (b) Penyajian data, (c) Penarikan kesimpulan. Keabsahan data dalam penelitian kualitatif dilakukan agar data yang diperoleh dapat diuji dan dapat dipercaya. Pengujian keabsahan data menurut Cresswell (2019: 269) dapat diperoleh dengan cara "member checking". Pada penelitian ini member checking dilakukan oleh kedua pembimbing.

\section{HASIL DAN PEMBAHASAN}

Pada bagian ini peneliti menyajikan dan membahas data yang telah diolah untuk menjawab permasalahan yang diangkat dalam penelitian yaitu mengenai analisis kesalahan penulisan huruf kapital pada karangan narasi menggunakan pedoman umum ejaan bahasa indonesia (PUEBI). Konteks penelitian ini disajikan sebagai berikut:

\section{a. Kesalahan penulisan huruf kapital yang dilakukan peserta didik dalam menulis karangan narasi}

Kemampuan peserta didik dalam penggunaan ejaan khususnya penggunaan huruf kapital perlu ditingkatkan kembali. Hal tersebut karena setelah dikoreksi banyak peserta didik yang melakukan kesalahan dalam penulisan huruf kapital. Peserta didik dalam menulis karangan narasi setelah peneliti baca dan analisis mengalami beberapa kesulitan diantaranya dalam mengembangkan ide pokok suatu paragraf, mengembangkan kalimat menjadi karangan narasi, membuat alur cerita, dan penggunaan huruf kapital yang belum sesuai dengan pedoman umum ejaan bahasa Indonesia (PUEBI).

Berdasarkan hasil analisis pekerjaan peserta didik dengan jumlah 23 responden diperoleh beberapa kesalahan dalam penggunaan huruf kapital, dalam hal ini peneliti akan menyajikan 2 karangan narasi hasil tulisan peserta didik.

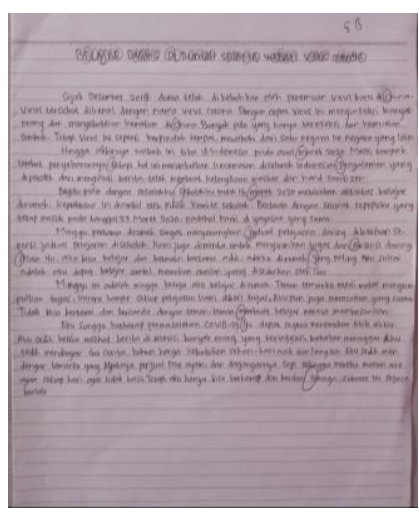

Gambar 4.1 Karangan narasi Idan

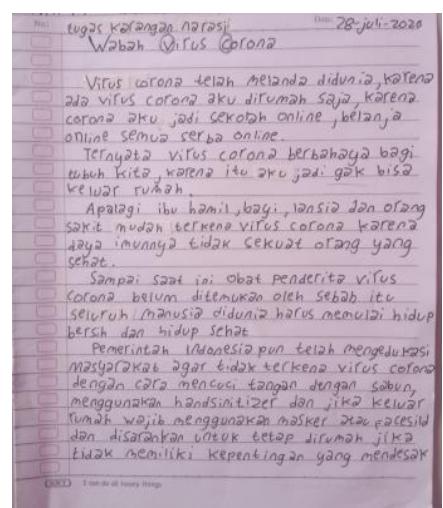

Gambar 4.2 Karangan narasi Ani 
Berdasarkan gambar 4.1 dapat diperoleh analisis bahwa pada tulisan karangan narasi yang telah Idan susun tersebut terdapat beberapa kesalahan. Kesalahan yang dilakukan oleh Idan salah satunya yaitu berkaitan dengan penggunaan huruf kapital pada judul karangan narasi, nama geografi, nama bulan, penulisan huruf kapital pada awal kalimat. Berdasarkan tulisan karangan narasi yang telah disusun oleh Idan terdapat kesalahan sejumlah 49. Berdasarkan Pedoman Umum Ejaan Bahasa Indonesia menurut Sunendar (2016 : 11) penggunaan huruf kapital dipakai sebagai huruf pertama setiap kata (termasuk unsur kata ulang sempurna) di dalam judul buku, karangan, artikel, dan makalah serta nama majalah dan surat kabar, kecuali kata tugas, seperti di, ke, dari, dan, yang, dan untuk, yang tidak terletak pada posisi awal. Pada hal ini berdasarkan tulisan Idan dalam penulisan judul karangan narasi menggunakan huruf kapital semua.

Pada gambar 4.2 diperoleh hasil bahwa karangan narasi yang telah disusun oleh Ani setelah peneliti koreksi terdapat beberapa kesalahan dalam penggunaan huruf kapital. Kesalahan tersebut terdapat pada judul karangan. Berdasarkan tulisan karangan narasi tersebut dapat diperoleh informasi bahwa kemampuan Ani dalam penggunaan huruf kapital sudah baik, hal tersebut dapat dilihat dari jumlah tingkat kesalahan. Setelah dilakukan analisis penggunaan huruf kapital pada 23 peserta didik, terdapat beberapa kesalahan yang beragam antara satu peserta didik dengan yang lainnya.

Data yang telah disajikan di atas salah satunya ada peserta didik yang melakukan kesalahan paling banyak yaitu Idan dengan jumlah kesalahan sebanyak 49, sedangkan peserta didik yang memiliki tingkat kesalahan rendah yaitu Ani dengan jumlah kesalahan sebanyak 2. Perbedaan jumlah tingkat kesalahan yang dilakukan peserta didik dalam menulis karangan narasi menunjukkan bahwa tingkat pemahaman peserta didik dalam penggunaan huruf kapital yang sesuai dengan pedoman umum ejaan bahasa Indonesia (PUEBI) berbeda satu sama lain. Kesalahan penggunaan huruf kapital yang paling banyak dilakukan oleh peserta didik yaitu berkaitan dengan penggunaan huruf kapital pada awal kalimat dan tengah kalimat sebanyak 355, nama tahun, bulan, hari dan hari besar 5, dan nama geografi 20, sehingga total kesalahan setelah di analisis yaitu sebanyak 380 . 


\section{b. Penyebab peserta didik mengalami kesulitan dalam menulis karangan narasi}

Hasil penelitian menunjukkan bahwa peserta didik kelas V B yang berjumlah 23 peserta didik diperoleh beberapa kendala dalam menulis karangan narasi. Dari data yang telah peneliti analisis dapat diperoleh informasi bahwa dari 23 peserta didik, yang mengalami kesulitan sebanyak 14 peserta didik, sedangkan peserta didik yang tidak mengalami kesulitan yaitu sebanyak 9 peserta didik. Kesulitan yang dialami peserta didik antara lain ketika harus menulis ide pokok, menyusunnya menjadi sebuah narasi, dan mengembangkannya agar lebih menarik dan sesuai dengan isi teks tersebut.

Peserta didik harus menentukan tema terlebih dahulu sebelum mereka menulis. Apabila tema sudah ditentukkan maka peserta didik hanya perlu mengembangkannya menjadi sebuah karangan narasi. Kesulitan menuliskan tema juga ditemui ketika melakukan penelitian, sedangkan menurut Tarigan (2013: 167) tema merupakan gagasan utama atau pikiran pokok. Berdasarkan teori tersebut maka sebuah narasi harus diawali dan dimulai dari proses menentukan tema terlebih dahulu.

\section{c. Upaya yang dilakukan guru untuk mengatasi kesulitan peserta didik dalam} menulis karangan narasi

Untuk mengatasi permasalahan atau kesulitan yang dialami peserta didik yaitu dengan cara memberikan tugas kepada peserta didik untuk menulis karena sekarang sedang digiatkan adanya budaya literasi. Kegiatan menggiatkan budaya literasi pada masa pandemi covid-19 dilakukan dengan literasi media. Hal tersebut sebagai suatu wujud dukungan yang dilakukan oleh guru kelas untuk tetap melaksanakan gerakan literasi sekolah. Gerakan literasi sekolah (GLS) digunakan untuk memperkuat gerakan penumbuhan budi pekerti sebagaimana dituangkan pada Peraturan Menteri Pendidikan dan Kebudayaan Nomor 23 Tahun 2015.

Kegiatan literasi merupakan proses kegiatan pembiasaan membaca yang dilakukan peserta didik sebelum kegiatan pembelajaran dimulai. Adanya kegiatan membaca maka pengetahuan peserta didik menjadi lebih luas dan apabila diminta untuk membuat karangan maka peserta didik mempunyai ide atau gambaran dalam menulis serta perbendaharaan kosakata yang dimiliki peserta didik menjadi bertambah dengan adanya kegiatan membaca. Kegiatan literasi tetap dilaksanakan pada masa pandemi covid-19 salah satunya dengan cara guru memberikan perintah 
kepada peserta didik melalui group whatsApp untuk melakukan kegiatan membaca sebelum pelaksanaan pembelajaran jarak jauh dimulai, kemudian setiap peserta didik mengirimkan foto beserta dengan judul bacaan yang telah mereka baca baik itu teks fiksi ataupun non fiksi.

\section{d. Kebijakan yang diambil kepala sekolah untuk mengatasi permasalahan peserta didik}

Berdasarkan data yang telah diperoleh dari hasil wawancara, kepala sekolah mengetahui kesulitan yang dihadapi peserta didik. Hal tersebut beliau ketahui dari pelaksanaan rapat guru. Pelaksanaan rapat guru untuk mengetahui permasalahan yang guru hadapi selama di kelas rutin dilaksanakan, sehingga permasalahan yang ada dapat dicarikan solusi secara bersama-sama melalui kegiatan rapat guru tersebut. Kepala sekolah juga menyampaikan bahwa kebijakan yang beliau lakukan yaitu dengan cara membimbing peserta didik, serta memberikan tugas kepada guru kelasnya untuk membimbing peserta didik yang mengalami kesulitan dalam menulis karangan dan penulisan huruf kapital yang benar, selain dengan memberikan tugas dapat pula dengan memberikan jam tambahan kepada peserta didik yang mengalami kesulitan. Bimbingan tersebut diharapkan dapat membantu kesulitan peserta didik.

\section{KESIMPULAN}

Berdasarkan penelitian yang telah dilaksanakan, dapat diperoleh simpulan bahwa kesalahan penulisan huruf kapital pada karangan narasi menggunakan pedoman umum ejaan bahasa indonesia (PUEBI) masih sering dilakukan oleh peserta didik kelas V B Sekolah Dasar Negeri 1 Sokaraja Kulon. Hal tersebut dapat dilihat dari total kesalahan penulisan huruf kapital setelah peneliti analisis yaitu sebanyak 380 kesalahan, yang dilakukan oleh 23 peserta didik dalam menulis karangan narasi. Peserta didik dalam menulis karangan narasi memiliki beberapa kesulitan salah satunya yaitu berkaitan dengan menceritakan khayalan ke dalam bentuk tulisan, menentukkan ide atau menjabarkan ide pokok, membuat alur cerita, sulit dalam berimajinasi, bingung menulis isi karangan, mengembangkan suatu kalimat, dan memilih kosakata yang tepat. Upaya yang dilakukan oleh guru kelas terkait dengan kemampuan peserta didik dalam menulis karangan yaitu dengan cara sering memberikan tugas untuk menulis, karena sekarang sedang digiatkan budaya literasi. Literasi yang dilakukan oleh guru kelas yaitu berupa literasi media. 
Kepala sekolah mengetahui permasalahan yang dialami peserta didik melalui kegiatan rapat guru. Upaya yang dilakukan oleh kepala sekolah dengan cara membimbing peserta didik dengan cara mendata peserta didik yang mengalami kesulitan, serta memberi tugas kepada guru kelasnya untuk melakukan bimbingan berupa tambahan jam pelajaran bagi peserta didik yang mengalami kesulitan dalam menulis. Saran yang dapat diberikan peneliti kepada pihak sekolah salah satunya yaitu menambah sumber pustaka yang ada di perpustakaan, misalnya KBBI, buku mengenai keterampilan menulis, buku Pedoman Umum Ejaan Bahasa Indonesia (PUEBI). Guru hendaknya lebih menekankan pada pembelajaran mengenai penggunaan huruf kapital yang sesuai dengan pedoman umum ejaan bahasa Indonesia (PUEBI) sehingga kesalahan dalam penulisan huruf kapital tidak menjadi kebiasaan bagi peserta didik.

\section{DAFTAR PUSTAKA}

Ali \& Asrori. 2014. Metodologi dan Aplikasi Riset Pendidikan. Jakarta: PT Bumi Aksara.

Creswell, W. John. 2019. Research Design Pendekatan Metode Kualitatif, Kuantitatif, dan Campuran. Yogyakarta: Pustaka Pelajar.

Mansur, Q. Djariyo \& Mudzanatun. 2018. Kemampuan Siswa Sekolah Dasar Dalam Penggunaan Huruf Kapital Pada Teks Di Kebumen. Dalam Jurnal Penelitian Bahasa, Sastra, dan Pengajarannya. 3, (3), 11-17.

Nurudin. 2007. Dasar-Dasar Penulisan. Malang: Universitas Muhammadiyah Malang.

Sunendar, Dadang. 2016. Pedoman Umum Ejaan Bahasa Indonesia. Edisi Keempat. Jakarta: Badan Pengembangan dan Pembinaan Bahasa.

Tarigan, H. G. 2013. Menulis Sebagai Suatu Keterampilan Berbahasa. Bandung: CV Angkasa.

Tarigan, H. G. 2015. Membaca Sebagai Suatu Keterampilan. Bandung: CV Angkasa.

Undang-Undang Republik Indonesia Nomor 24 Tahun 2009. Tentang Bendera, Bahasa, Lambang Negara, serta Lagu Kebangsaan. Jakarta: Presiden Republik Indonesia. 